University of Nebraska - Lincoln

DigitalCommons@University of Nebraska - Lincoln

April 2007

\title{
Genetic structure in natural populations of barley/cereal yellow dwarf virus isolates from Alaska
}

\author{
N.L. Robertson \\ United States Department of Agriculture \\ Roy C. French \\ University of Nebraska-Lincoln, rfrench2@unl.edu
}

Follow this and additional works at: https://digitalcommons.unl.edu/plantpathpapers

Part of the Plant Pathology Commons

Robertson, N.L. and French, Roy C., "Genetic structure in natural populations of barley/cereal yellow dwarf virus isolates from Alaska" (2007). Papers in Plant Pathology. 9.

https://digitalcommons.unl.edu/plantpathpapers/9

This Article is brought to you for free and open access by the Plant Pathology Department at DigitalCommons@University of Nebraska - Lincoln. It has been accepted for inclusion in Papers in Plant Pathology by an authorized administrator of DigitalCommons@University of Nebraska - Lincoln. 


\title{
Genetic structure in natural populations of barley/cereal yellow dwarf virus isolates from Alaska
}

\author{
N. L. Robertson ${ }^{1}$ and R. French ${ }^{2}$ \\ ${ }^{1}$ United States Department of Agriculture, Agricultural Research Service, Subarctic Agricultural Research Unit, \\ Arctic Germplasm Introduction and Research Project, University of Alaska-Fairbanks, Palmer, AK, U.S.A. \\ ${ }^{2}$ United States Department of Agriculture, Agricultural Research Service, University of Nebraska-Lincoln, \\ Lincoln, NE, U.S.A.
}

Received June 13, 2006; accepted November 30, 2006; published online January 12, 2007

(C) Springer-Verlag 2007

\section{Summary}

The genetic structure of natural populations of Alaskan barley yellow dwarf virus (BYDV)-PAV, BYDV-PAS, and cereal yellow dwarf virus (CYDV)RPV from barley (Hordeum vulgare L.) and oats (Avena sativa L.) in Alaska were analyzed between 2002 and 2004. PCR products spanning the viral coat protein gene of 187 isolates were cloned and sequenced. The majority $(78 \%)$ were similar to BYDV-PAS, 19\% were similar to CYDV-RPV, and only about $3 \%$ resembled BYDV-PAV. The CYDVRPV isolates clustered in three groups: 44, 17, and 39\% resembled RPS-like CP from Mexico, resembled RPV-like CP from New York, or formed

\footnotetext{
Note: Nucleotide sequence data reported are available in the GenBank databases under the accession number(s): BYDV-PAS: DQ683252, DQ907011-DQ907116, DQ907122-DQ907160; BYDV-PAV: DQ907117DQ907121; CYDV-RPV: DQ910730-DQ910761, DQ988082-DQ988108.

Author's address: Nancy L. Robertson, United States Department of Agriculture, Agricultural Research Service, Subarctic Agricultural Research Unit, Arctic Germplasm Introduction and Research Project, University of Alaska-Fairbanks, Palmer Research Station, 533 East Fireweed Avenue, Palmer, AK 99645, U.S.A. e-mail: pfnlr@uaa.alaska.edu
}

a unique clade that was RPV/RPS recombinant $\mathrm{CP}$, respectively. The patterns of genetic variation of PAS and RPV varied little over time or with respect to host plant. The difference in spatial and temporal population genetic structures of the PAS and RPV isolates suggests that these two viruses are influenced by different agroecological factors. Sequence of PCR products spanning the carboxyl terminus of the polymerase gene, the intergenic region, and most of the coat protein gene of RPV revealed two probable ancestral recombination events for some isolates.

\section{Introduction}

Plant viruses with RNA genomes have high potential for variation in spatial and temporal genetic composition through mutation, recombination, and drift $[6,7]$. However, most genetic diversity studies on plant viruses have concluded that plant virus populations tend to be genetically stable [6] and that resistance genes in corresponding host plants remain durable [8].

We were interested in examining the population structure of Barley yellow dwarf virus-PAV (BYDV- 
PAV) and Cereal yellow dwarf virus-RPV (CYDVRPV) strains in barley (Hordeum vulgare L.) and oats (Avena sativa L.), the two main cereal crops in Alaska. Members of these two virus species and at least six other species cause BYD disease, the most destructive viral disease of the small grains throughout the world [11]. The viral nature of BYD disease was first identified in 1951 [20] from diseased barley plants growing in California. Biological properties of BYD were described by W. F. Rochow in numerous publications during the 1960-1980s, defining distinct strains or serotypes and establishing intimate aphid vector/virus relationships [4]. Taxonomically, the viruses responsible for BYD disease belong to the family Luteoviridae: genus Luteovirus, BYDV-PAV, BYDV-MAV, BYDV- PAS; genus Polerovirus, cereal yellow dwarf virus-RPV, CYDVRPS; and three species not yet assigned to a genus, BYDV-SGV, BYDV-RMV, and BYDV-GPV [5, 13, 15]. The species name, in part, is determined from its most efficient aphid vector: $\mathrm{MAV}=$ Sitobion (Macrosiphum) avenae, $\mathrm{RPV}=$ Rhopalosiphum padi, $\mathrm{RMV}=$ Rhopalosiphum maidis, $\mathrm{SGV}=$ Schizaphis graminum, and $\mathrm{PAV}=R$. padi and $S$. avenae. B/ CYD viruses consist of $\sim 5.3-5.8 \mathrm{~kb}$ in a ssRNA genome that is divided into six ORFs; the genera are distinguished by gene size and arrangement [5]. The $5^{\prime}$-half consists of two major overlapping genes involved in replication (ORF 1-2) and is not conserved between genera; CYDV has an extra ORF $(0)$ at the $5^{\prime}$ end. In contrast, the $3^{\prime}$-half is the most conserved portion of the genome, containing the "Luteoviridae block", which consists of ORF 4, situated within the major coat protein gene (ORF 3) that is fused to ORF 5; BYDV has an extra ORF (6) at the $3^{\prime}$ terminus [17]. Despite the plethora of BYD research completed during the last 50 years, very little is known on the genetic structure of the B/ CYDVs in natural populations.

Although BYD most likely had occurred in the small grains in Alaska since their agricultural introduction over the last century, reported diseases of grasses and cereals are largely out of date and confined to parasitic fungi [26]. The first confirmation of B/CYDV in Alaska barley and oats occurred in 2001 [22]. Crops grown in Alaska are geographically isolated from other agricultural regions by distance, water, and mountain ranges. Fields of barley and oats are relatively small and scattered, vary in planting dates from May through August, and are used for ground cover or harvested for animal feed. We were interested in obtaining genetic information on Alaskan B/CYDV isolates to help determine their relationships within and between fields, variations in consecutive years, and their likeness to other isolates throughout the world. In this paper, we report the genetic analysis of $187 \mathrm{~B} / \mathrm{CYDV}$ Alaskan isolates from oat and barley spanning three consecutive years (2002-2004).

\section{Materials and methods}

\section{Virus isolates}

Between May and October in 2002-2004, barley and oat plants were surveyed for BYD in Palmer (P), Alaska in fields that were within $24 \mathrm{~km}$ of each other. Due to the unpredictable occurrence of a barley or oat crop on a particular site in consecutive years, sites P1, P2, and P5 were surveyed once (2003), site P3 was surveyed in 2002 and 2004, and site P4 was surveyed in 2002-2004. Barley plants in a field on the University of Alaska Experimental Research Station in Fairbanks, site F6, were also surveyed in 2003. Plants with yellow (barley) or orange/red (oats) leaves were detached, placed in a plastic bag, and stored at $4{ }^{\circ} \mathrm{C}$ if processed within several days, or $-80^{\circ} \mathrm{C}$ for long-term storage. Green leaves from several nonsymptomatic plants per site were similarly processed. Tissue from the same leaves were used in enzymelinked immunosorbent (ELISA) and reverse transcription polymerase chain reaction (RT-PCR) assays.

\section{Serology}

Agdia PathoScreen kits utilizing DAS-ELISA with alkaline phosphatase enzyme conjugate were used as directed for PAV, MAV, and SGV; RPV was similarly tested with a compound direct ELISA assay from Agdia Inc. (Elkhart, IN). Briefly, leaf samples $(0.20 \mathrm{~g})$ were ground in $1.0 \mathrm{ml}$ distilled water with mortar and pestle and $10 \mu \mathrm{l}$ of the extract was mixed with $90 \mu \mathrm{l}$ extraction buffer, applied to provided microlitre plates, and tested together with a positive control, according to manufacturer directions. All assays were analyzed on a VERSAmax microplate reader (Molecular Devices, Sunnydale, CA, USA) at $405 \mathrm{~nm}$, with positive readings defined as being at least three times that of the buffer control.

Reverse transcriptase-polymerase chain reaction, cloning, and nucleotide sequencing

Total nucleic acid extractions from leaves and subsequent RT-PCR assays that target the coat protein (CP) gene [23] 
were performed as described previously. Briefly, $0.5 \mathrm{~g}$ tissue was ground in liquid nitrogen, mixed with $4 \mathrm{ml}$ buffer, and emulsified with equal volume of phenol. It was then vortexed and centrifuged, and the nucleic acid in the aqueous phase was precipitated with sodium acetate $(\mathrm{pH} 5.2)$ and 2.5 volumes of ethanol. Synthesis of cDNA was achieved with 1-2 $\mu \mathrm{l}$ nucleic acid extract, $10 \mathrm{pmol}$ reverse primer $\mathrm{Lu} 4$, and AMV-reverse transcriptase (Promega, Madison, WI), dNTP, and provided buffer as directed. DNA targeting the coat protein gene was amplified with $5 \mu \mathrm{l} \mathrm{cDNA}, 10 \mathrm{pmol}$ of each primer (Lu 4 and Lu 1-forward), dNTP, and buffer provided with Taq DNA polymerase (Roche Diagnostic Corp., Indianapolis, IN) in a $100-\mu 1$ reaction. Samples were placed in a GenAmp ${ }^{\circledR}$ PCR System 9700 (PE Applied Biosystems, Foster City, CA) and incubated in the temperature/ time regime as previously described [23]. PCR products were visualized and extracted on ethidium-bromide-stained agarose gels, and purified using a QIAquick Gel Extraction Kit (QIAGEN Inc., Valencia, CA). The amplified DNA was cloned into pGem-T easy (Promega), and introduced by transformation into Escherichia coli XL-2 Blue (Stratagene, La Jolla, CA), and the plasmids were sent to Davis Sequencing Inc. (Davis, CA) for automated DNA sequencing of the coat protein. The nucleic acid preparations from which RPV isolates were detected were used for RT-PCR again by incorporating primers Pol 1 (forward) and $\mathrm{Lu} 4$ in a protocol described by Geske et al. [9] that targeted the carboxyl terminus of the polymerase gene (ORF 2), the intergenic region, and the $\mathrm{CP}$ gene; the subsequent cloning and sequencing of the predicted $\sim 1400$ product were processed as described previously for the $\mathrm{CP}$ gene.

\section{Genetic analysis}

Definitive identification of each isolate detected by RTPCR, was determined using 502 nt of the CP gene sequence (excluding the $3^{\prime}$ - and $5^{\prime}$-termini that matched the primers). Preliminary identification for relatedness among the isolates was based on sequence alignments in Sequencher 4.5 (Genes Codes Corp., Ann Arbor, MI), and representative sequenced isolates were compared with other isolates in the sequence databases in NCBI (National Center for Biotechnology Information) using Basic Local Alignment Search Tool (BLASTn) nucleotide-nucleotide searches.

Sequences were aligned and neighbor-joining (NJ) trees for PAS/PAV and RPV were generated with ClustalX [28]. Maximum parsimony analyses, implemented in PAUP [27], produced trees identical to the NJ trees (not shown). Each of the 187 isolates was identified as: virus species (PAS, PAV or RPV), sample number (plant) within specific site, nearest city ( $P$ Palmer, $F$ Fairbanks), plant species ( $b$ barley, $o$ oat), and year (2002, -03, or -04) of collection (Figs. 1 and 2). Mean sequence diversity among isolates from each collection site was determined using the DnaSP computer program [24]. Genetic differentiation of populations among sites was assessed using the methods of Lynch and Crease [12] and Hudson [10], as implemented in DnaSP version 4. Analysis of molecular variation (AMOVA) was done using Arlequin [25]. The significance of each genetic differentiation statistic was estimated by 1000 permutations of the data. The program PhylPro [31] was used to identify possible phylogenetic conflicts in the sequence data sets. A difference of sums of squares (DSS) method that utilizes approximate distance-based phylogenetic methods [16] as implemented in TOPALi [18] was used to identify likely recombination breakpoints. The sliding window size was set at 250 and the step size was set at 10. Sliding window analysis of pairwise nucleotide distances was also done using DnaSP.

\section{Results}

\section{ELISA and RT-PCR}

A total of 300 oat and barley plants were collected and assayed for B/CYDV by ELISA and PCR using primers $\mathrm{Lu} 1$ and $\mathrm{Lu} \mathrm{4}$. ELISA assays for MAV and SGV were negative for all three years. In 2002, PAV was detected in 62 of 132 plants and RPV was found in 12 samples. PCR assays detected B/CYDV in 98 samples. Similarly, B/CYDV was identified in 52 of 104 pants sampled in 2003, of which 16 were positive for PAV and 13 for RPV by ELISA. One barley plant was found to have both PAV and RPV. Sixty-four plants were assayed in 2004 with 52 positive for B/CYDV by PCR, with 42 identified as PAV and eight identified as RPV by ELISA. Thus, the majority of infected plants had PAV $(84,55$, and $84 \%$ in 2002, 2003, and, 2004, respectively).

\section{Barley yellow dwarf virus}

PCR products resulting from amplification by primers $\mathrm{Lu} 1$ and $\mathrm{Lu} 4$ were cloned and sequenced. Of 187 total clones, 151 PAV-like sequences were obtained (DQ683252, DQ907011-DQ907160). Although the BYDV isolates from the Palmer sites were serologically related to $\mathrm{PAV}$, their $\mathrm{CP}$ sequences aligned most significantly with PAS isolates in GenBank (Blastn). For example, the CP nts for PAS28P2b03 (accession no. DQ907106) were $98 \%$ identical to PAS-129 (accession no. 


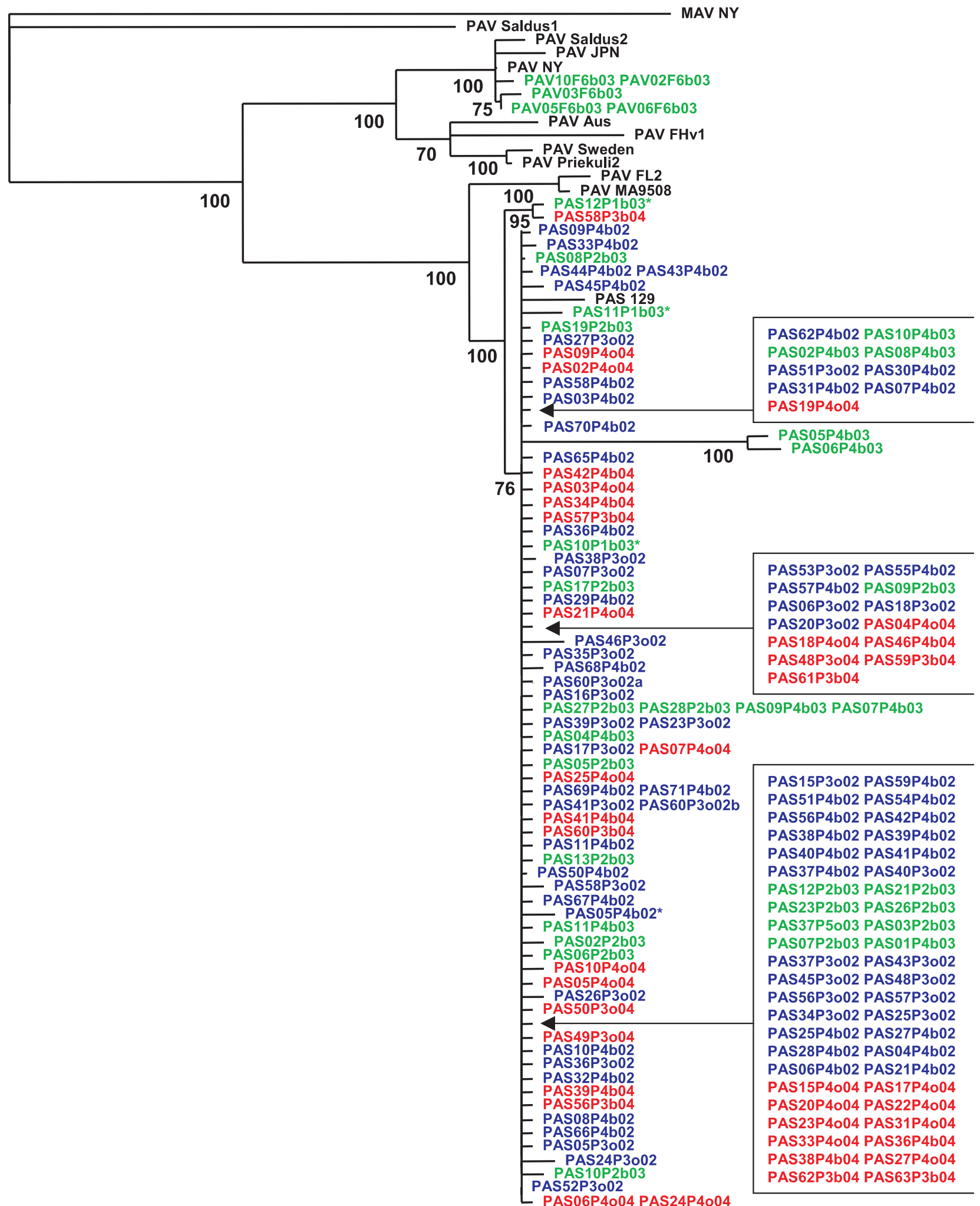


Table 1. Percent sequence identities between Alaska BYDV and CYDV phylogenetic clusters and other BYDV/CYDV sequences. The first number is percent nucleotide identity of the coat protein gene, and the second and third numbers are percent amino acid identities of the coat protein and ORF 4, respectively. The last row gives the percent sequence identities within Alaska BYDV and CYDV phylogenetic clusters

\begin{tabular}{llllll}
\hline Viruses & AK PAV & AK PAS & AK RPV & AK RPS & AK RPV/RPS recombinant \\
\hline PAV NY & 99.599 .599 .1 & 89.585 .889 .5 & 53.348 .228 .0 & 53.147 .628 .2 & 53.148 .128 .0 \\
PAV Aust & 94.096 .085 .1 & 89.085 .887 .3 & 53.446 .429 .6 & 52.845 .828 .0 & 53.346 .329 .4 \\
PAV FL2 & 89.484 .188 .1 & 96.296 .896 .1 & 53.047 .026 .4 & 52.646 .426 .4 & 53.146 .926 .4 \\
PAS & 89.184 .988 .1 & 98.396 .996 .1 & 53.147 .626 .4 & 53.347 .026 .4 & 53.547 .526 .4 \\
MAV NY & 78.382 .370 .8 & 78.282 .375 .2 & 53.445 .229 .2 & 52.842 .128 .4 & 53.344 .928 .6 \\
SGV & 69.359 .157 .9 & 68.660 .358 .0 & 51.544 .630 .0 & 50.944 .529 .8 & 51.444 .629 .9 \\
RPV NY & 53.147 .630 .6 & 53.247 .030 .7 & 99.199 .198 .3 & 90.191 .088 .5 & 94.998 .197 .1 \\
RPV Aust & 52.547 .027 .5 & 52.447 .628 .4 & 92.293 .288 .4 & 90.291 .388 .2 & 90.793 .688 .2 \\
RPV Iran & 55.849 .627 .1 & 55.647 .727 .3 & 93.293 .893 .3 & 90.390 .585 .8 & 92.693 .493 .0 \\
RPS & 52.347 .030 .6 & 52.846 .430 .7 & 90.890 .889 .2 & 98.599 .098 .8 & 93.890 .989 .3 \\
GPV & 54.244 .629 .8 & 54.043 .929 .2 & 84.678 .099 .4 & 81.373 .279 .8 & 84.477 .588 .1 \\
RMV IL & 52.744 .328 .6 & 52.045 .330 .2 & 61.860 .547 .3 & 61.759 .050 .2 & 61.460 .347 .0 \\
within & 99.598 .999 .7 & 99.398 .899 .4 & 99.599 .699 .7 & 99.299 .299 .2 & 98.598 .197 .5 \\
\hline
\end{tabular}

AF218798, 2936-3466 nts). This was confirmed by phylogenetic analysis in that all 146 isolates from the Palmer sites (P1-P5) clustered with PAS-129 (Fig. 1). The remaining five isolates from the Fairbanks site (F6) were associated with PAV isolates from New York (NY PAV), Japan (JPN PAV), and Latvia (Saldus 2), (Fig. 1). The Alaska PAV and PAS isolates exhibited less than $1 \%$ per site average pairwise nucleotide differences, or diversities (Table 1). Average pairwise $\mathrm{CP}$ amino acid differences were just over $1 \%$, while amino acid variation in ORF 4 was only half of that for CP (Table 1). The genetic diversity of the isolates from Palmer sites was about the same within and between fields (Table 2a). The PAS isolates from Palmer sites did not have any host (barley vs. oats) preference as only $0.2 \%$ of the total variation was due to host effects as determined by AMOVA. Among-year differences accounted for only $1.6 \%$ of the total. Genetic differentiation among populations was measured by two test statistics: Nst, and Snn. Nst values range from 0.0 for no differentiation to 1.0 for complete differentiation [12]. Snn is also 1.0 for complete differentiation, whereas the value for no differentiation depends on the number of populations and sample sizes [10]. For example, assuming equal sample sizes, the minimum Snn value is 0.5 for two populations, 0.25 for four populations, etc. Nst and Snn for the Palmer PAS populations were 0.0750 and 0.2735 , respectively, thus indicating low dif-

Fig. 1. Phylogenetic tree showing relationships of 151 Barley yellow dwarf virus-PAS/PAV isolates from Alaska with 12 BYDV isolates from other regions in the world by comparing their nucleotide sequences in the coat protein gene. The Alaskan isolates are denoted in blue (2002), green (2003), and red (2004) as: $P A V$, $x x$, sample number on site, $P$ Palmer or $F$ Fairbanks, site number (1-6), plant species, $b$ barely or $o$ oat, and year $=02$, 03, or 04. Other isolates are depicted as follows with isolate name, country, and accession number in parenthesis: NY MAV (BYDV-MAV-PS1, USA, X17260), PAV Saldus1 (BYDV-PAV-Saldus1, Latvia, AJ563410), PAV Saldus2 (BYDV-PAV-Saldus2, Latvia, AJ563411), PAV JPN (BYDV-PAV-JPN, Japan, D85783), PAV NY (BYDV-PAV-NY, USA, X56050), PAV Aus (BYDV-PAV-Aus, Australia, M21347), PAV FHv1 (BYDV-PAV-FH1, France, AJ223588), PAV Sweden (BYDV-PAV-Sweden, Sweden, AJ563415), PAV Priekuli2 (BYDV-PAV-Priekuli2, Latvia, AJ563414), PAV FL2 (BYDV-PAV-FL2, France, AJ223586), PAV MA9508 (BYDV-PAV9508, Morocco, AJ007919), and PAS 129 (BYDV-PAS, USA, AF218798). Isolates that occurred in the same plant with CYDV-RPV isolates are denoted with an asterisk. Only nodes with bootstrap values $\geq 70 \%$ (out of 1000 ) were retained 
Table 2. Nucleotide diversity, $\pi$ (defined as the average number of nucleotide substitutions per site for all pairwise comparisons), among CP sequences of (a) BYDV or (b) CYDV isolates within field samples (on the diagonal in bold) and between field samples (below the diagonal). As the P5o03 sample in (a) BYDV, and the P4b02, P3o03, and P4b04 samples in (b) CYDV were comprised of only a single sequence, within field diversity values are not applicable (N/A). Values in parentheses are standard errors computed over 500 bootstrap replicates. An asterisk indicates sample pairs for which a null hypothesis of no genetic differentiation was rejected $(P=0.05)$

\begin{tabular}{|c|c|c|c|c|c|c|c|c|c|c|c|}
\hline $\begin{array}{l}\text { Fields }^{\mathrm{a}} \text { (no. } \\
\text { of isolates) }\end{array}$ & $\mathrm{P} 3 \mathrm{o} 02$ & $\mathrm{P} 4 \mathrm{~b} 02$ & P1b03 & $\mathrm{P} 2 \mathrm{~b} 03$ & $\mathrm{P} 4 \mathrm{~b} 03$ & P5o03 & F6b03 & P3o04 & P3b04 & P4b04 & $\mathrm{P} 4 \mathrm{o} 04$ \\
\hline \multicolumn{12}{|l|}{ (a) BYDV } \\
\hline P3o02 (33) & $\begin{array}{l}0.0054 \\
(0.0013)\end{array}$ & & & & & & & & & & \\
\hline P4b02 (44) & $\begin{array}{l}0.0067 \\
(0.0016)\end{array}$ & $\begin{array}{l}0.0071 \\
(0.0019)\end{array}$ & & & & & & & & & \\
\hline P1b03 (3) & $\begin{array}{l}0.0117 * \\
(0.0027)\end{array}$ & $\begin{array}{l}0.0122 * \\
(0.0028)\end{array}$ & $\begin{array}{l}0.0173 \\
(0.0046)\end{array}$ & & & & & & & & \\
\hline P2b03 (17) & $\begin{array}{l}0.0049 \\
(0.0011)\end{array}$ & $\begin{array}{l}0.0060 \\
(0.0016)\end{array}$ & $\begin{array}{l}0.0114 \\
(0.0028)\end{array}$ & $\begin{array}{l}0.0043 \\
(0.0012)\end{array}$ & & & & & & & \\
\hline P4b03 (9) & $\begin{array}{l}0.0167 * \\
(0.0029)\end{array}$ & $\begin{array}{l}0.0162 * \\
(0.0029)\end{array}$ & $\begin{array}{l}0.0223^{*} \\
(0.0038)\end{array}$ & $\begin{array}{l}0.00156^{*} \\
(0.0028)\end{array}$ & $\begin{array}{l}0.0220 \\
(0.0038)\end{array}$ & & & & & & \\
\hline P5o03 (1) & $\begin{array}{l}0.0030 \\
(0.0008)\end{array}$ & $\begin{array}{l}0.0045 \\
(0.0014)\end{array}$ & $\begin{array}{l}0.0100 \\
(0.0027)\end{array}$ & $\begin{array}{l}0.0022 \\
(0.0006)\end{array}$ & $\begin{array}{l}0.0146 \\
(0.0029)\end{array}$ & $\begin{array}{l}\mathbf{N} / \mathbf{A} \\
(\mathbf{N} / \mathbf{A})\end{array}$ & & & & & \\
\hline F6b03 (5) & $\begin{array}{l}0.1107 * \\
(0.0132)\end{array}$ & $\begin{array}{l}0.1087 * \\
(0.0130)\end{array}$ & $\begin{array}{l}0.1053^{*} \\
(0.0129)\end{array}$ & $\begin{array}{l}0.1095 * \\
(0.0132)\end{array}$ & $\begin{array}{l}0.1140 * \\
(0.0127)\end{array}$ & $\begin{array}{l}0.1100^{*} \\
(0.0134)\end{array}$ & $\begin{array}{l}0.0040 \\
(0.0018)\end{array}$ & & & & \\
\hline P3o04(3) & $\begin{array}{l}0.0057 \\
(0.0014)\end{array}$ & $\begin{array}{l}0.0066 \\
(0.0018)\end{array}$ & $\begin{array}{l}0.0118 * \\
(0.0028)\end{array}$ & $\begin{array}{l}0.0052 \\
(0.0014)\end{array}$ & $\begin{array}{l}0.0162 * \\
(0.0029)\end{array}$ & $\begin{array}{l}0.0034 \\
(0.0010)\end{array}$ & $\begin{array}{l}0.1096 * \\
(0.0131)\end{array}$ & $\begin{array}{l}0.0060 \\
(0.0017)\end{array}$ & & & \\
\hline P3b04 (8) & $\begin{array}{l}0.0057 \\
(0.0016)\end{array}$ & $\begin{array}{l}0.0069 \\
(0.0019)\end{array}$ & $\begin{array}{l}0.0120 * \\
(0.0028)\end{array}$ & $\begin{array}{l}0.0055 \\
(0.0016)\end{array}$ & $\begin{array}{l}0.0171 * \\
(0.0032)\end{array}$ & $\begin{array}{l}0.0037 \\
(0.0015)\end{array}$ & $\begin{array}{l}0.1114 * \\
(0.0132)\end{array}$ & $\begin{array}{l}0.0060 \\
(0.0017)\end{array}$ & $\begin{array}{l}\text { 0.0059 } \\
(0.0022)\end{array}$ & & \\
\hline P4b04 (7) & $\begin{array}{l}0.0063 \\
(0.0015)\end{array}$ & $\begin{array}{l}0.0073 \\
(0.0019)\end{array}$ & $\begin{array}{l}0.0111 \\
(0.0028)\end{array}$ & $\begin{array}{l}0.0059 \\
(0.0016)\end{array}$ & $\begin{array}{l}0.0174 * \\
(0.0031)\end{array}$ & $\begin{array}{l}0.0042 \\
(0.0014)\end{array}$ & $\begin{array}{l}0.1092 * \\
(0.0130)\end{array}$ & $\begin{array}{l}0.0065 \\
(0.0017)\end{array}$ & $\begin{array}{l}0.0064 \\
(0.0017)\end{array}$ & $\begin{array}{l}0.0071 \\
(0.0022)\end{array}$ & \\
\hline P4o04 (21) & $\begin{array}{l}0.0049 \\
(0.0015)\end{array}$ & $\begin{array}{l}0.0064 \\
(0.0015)\end{array}$ & $\begin{array}{l}0.0113 \\
(0.0029)\end{array}$ & $\begin{array}{l}0.0046 \\
(0.0015)\end{array}$ & $\begin{array}{l}0.0165 * \\
(0.0031)\end{array}$ & $\begin{array}{l}0.0027 \\
(0.0013)\end{array}$ & $\begin{array}{l}0.1113 * \\
(0.0133)\end{array}$ & $\begin{array}{l}0.0054 \\
(0.0017)\end{array}$ & $\begin{array}{l}0.0052 \\
(0.0019)\end{array}$ & $\begin{array}{l}0.0057 \\
(0.0018)\end{array}$ & $\begin{array}{l}0.0053 \\
(0.0027)\end{array}$ \\
\hline $\begin{array}{l}\text { Fields (no. } \\
\text { of isolates) }\end{array}$ & $\mathrm{P} 4 \mathrm{~b} 02$ & & 3002 & F6b03 & P1b & & $\mathrm{P} 2 \mathrm{~b} 03$ & $\mathrm{P} 3 \mathrm{o} 04$ & & 4b04 & $\mathrm{P} 4 \mathrm{o} 04$ \\
\hline
\end{tabular}

\begin{tabular}{|c|c|c|c|c|c|c|c|c|}
\hline \multicolumn{9}{|l|}{ (b) CYDV } \\
\hline P4b02 (1) & $\begin{array}{l}\mathbf{N} / \mathbf{A} \\
(\mathbf{N} / \mathbf{A})\end{array}$ & & & & & & & \\
\hline P3o02 (10) & $\begin{array}{l}0.0614 \\
(0.0095)\end{array}$ & $\begin{array}{l}\mathbf{0 . 0 1 5 9} \\
(0.0026)\end{array}$ & & & & & & \\
\hline F6b03 (5) & $\begin{array}{l}0.0349 \\
(0.0071)\end{array}$ & $\begin{array}{l}0.0826^{*} \\
(0.0107)\end{array}$ & $\begin{array}{l}\mathbf{0 . 0 1 9 0} \\
(\mathbf{0 . 0 0 3 6})\end{array}$ & & & & & \\
\hline P1b03 (11) & $\begin{array}{l}0.0367 \\
(0.0050)\end{array}$ & $\begin{array}{l}0.0491 \\
(0.0065)\end{array}$ & $\begin{array}{l}0.0491 \\
(0.0075)\end{array}$ & $\begin{array}{l}0.0465 \\
(0.0060)\end{array}$ & & & & \\
\hline $\mathrm{P} 2 \mathrm{~b} 03$ (2) & $\begin{array}{l}0.0397 \\
(0.0063)\end{array}$ & $\begin{array}{l}0.0375 \\
(0.0057)\end{array}$ & $\begin{array}{l}0.0608 \\
(0.0080)\end{array}$ & $\begin{array}{l}0.0397 \\
(0.0052)\end{array}$ & $\begin{array}{l}0.0653 \\
(0.0103)\end{array}$ & & & \\
\hline P3o04 (1) & $\begin{array}{l}0.0139 \\
(0.0049)\end{array}$ & $\begin{array}{l}0.0618 \\
(0.0096)\end{array}$ & $\begin{array}{l}0.0377 \\
(0.0075)\end{array}$ & $\begin{array}{l}0.0358 \\
(0.0049)\end{array}$ & $\begin{array}{l}0.0367 \\
(0.0055)\end{array}$ & $\begin{array}{l}\mathbf{N} / \mathbf{A} \\
(\mathbf{N} / \mathbf{A})\end{array}$ & & \\
\hline P4b04 (1) & $\begin{array}{l}0.0635 \\
(0.0104)\end{array}$ & $\begin{array}{l}0.0113 \\
(0.0022)\end{array}$ & $\begin{array}{l}0.0853 \\
(0.0116)\end{array}$ & $\begin{array}{l}0.0465 \\
(0.0116)\end{array}$ & $\begin{array}{l}0.0327 \\
(0.0055)\end{array}$ & $\begin{array}{l}0.0635 \\
(0.0105)\end{array}$ & $\begin{array}{l}\mathbf{N} / \mathbf{A} \\
(\mathbf{N} / \mathbf{A})\end{array}$ & \\
\hline $\mathrm{P} 4 \mathrm{o} 04$ (5) & $\begin{array}{l}0.0317 \\
(0.0052)\end{array}$ & $\begin{array}{l}0.0396 \\
(0.0061)\end{array}$ & $\begin{array}{l}0.0548 \\
(0.0075)\end{array}$ & $\begin{array}{l}0.0381 \\
(0.0050)\end{array}$ & $\begin{array}{l}0.0331 \\
(0.0055)\end{array}$ & $\begin{array}{l}0.0282 \\
(0.0048)\end{array}$ & $\begin{array}{l}0.0361 \\
0.0062\end{array}$ & $\begin{array}{l}0.0367 \\
(0.0059)\end{array}$ \\
\hline
\end{tabular}

${ }^{\mathrm{a}}$ Each site (field) is identified as: $P$ Palmer or $F$ Fairbanks, field number $=1-6, b$ barley (host) or $o$ oats (host), year $=02-04$. 


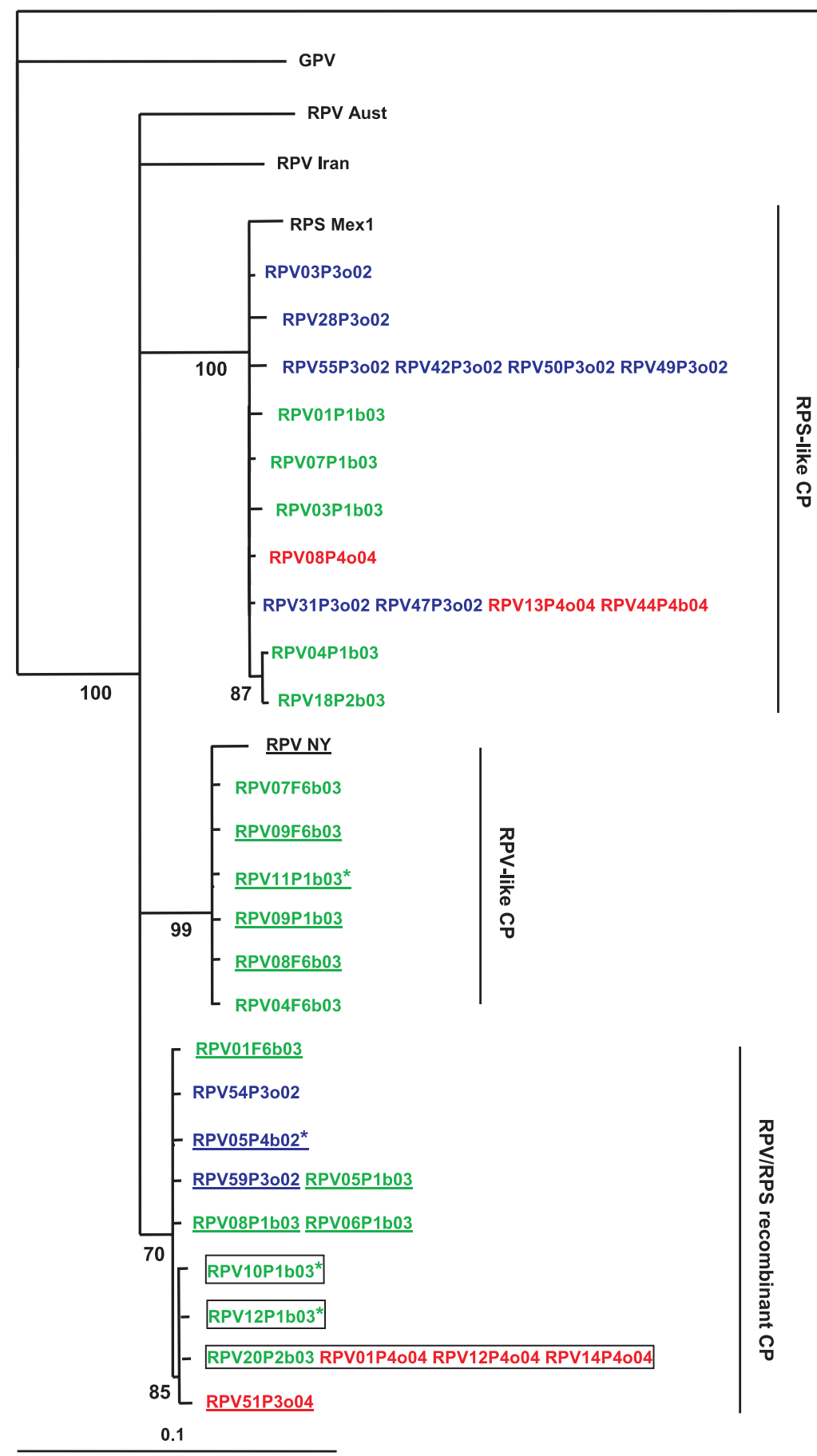

Fig. 2. Phylogenetic tree depicting relationships among 36 Alaskan Cereal yellow dwarf virus (CYDV)-RPV isolates by comparing nucleotide sequences of the coat protein gene. Names are encoded in blue (2002), green (2003), and red (2004) as: virus $=\mathrm{RPV}$, $\mathrm{xx}$ sample number within field, $P$ Palmer or $F$ Fairbanks (location), site number (1-6), plant species $(b$ barley or $o$ oats), and year $=02,03$, or 04. Also included are several CYDV-RPV isolates outside of Alaska: RPV Aus (CYDV-RPV, Australia, AF020090), RPS Mex1 (CYDV-RPS, Mexico, AF235168), RPV IR (CYDV-RPV-IR, Iran, AY450425), RPV NY (CYDV-RPV-NY, New York, USA, D10206), and two members of unassigned virus species in the family Luteoviridae, GPV (BYDV-GPV, China, L10356) and RMV IL (BYDV-RMV-ILL, USA, Z14123). Isolates that have RPV-like sequences in the carboxyl terminus of the polymerase gene and intergenic region are underlined. Isolates that represent double recombinants are enclosed in a box, and isolates that occurred in the same plant with BYDV-PAS isolates are denoted with an asterisk. Analysis completed with a bootstrap of 1000 replicates; only nodes with bootstrap values $\geq 70 \%$ are shown 
ferentiation across all sites and years. Genetic differentiation was complete between Palmer and Fairbanks sites, as NY-PAV- like isolates occurred exclusively in the latter.

\section{Cereal yellow dwarf virus}

Between 2002 and 2004, 32 RPV isolates were identified from the $\mathrm{CP}$ nucleotide sequences derived from PCR fragments with Lu1/Lu4 primers (accession numbers, DQ910730-DQ910761). However, conflicting ELISA and PCR results occurred when three barley plants $(\# 10-12)$ from field P1 in 2003 tested positive serologically for only RPV and not PAV/PAS, but produced only PAS CP sequences from the PCR product: [isolate (accession number)] PAS10P1bo3 (DQ907087), PAS11P1b03 (DQ907088), PAS12P1b03(DQ907089). The additional presence of RPV was confirmed in these three plants, and another plant $(05 \mathrm{P} 4 \mathrm{o} 02)$ by cloning and sequencing the $\sim 1400$-bp fragment derived from reamplification of the stored cDNA with polerovirus-specific primers: [isolate (accession number)] RPV10P1bo3 (DQ988098), RPV11P1b03 (DQ988099), RPV12P1b03 (DQ988100), RPV05P4o02 (DQ988088). These four additional RPV isolates were incorporated and analyzed with the original $32 \mathrm{RPV}$ isolates (Fig. 2, Table 2b).

An additional 23 isolates from 2002 to 2004 RPV nucleic extracts were similarly processed to obtain the longer RPV sequences for analysis (accession numbers: DQ988082-DQ988087, DQ988089DQ988097, DQ988101-DQ988108). Phylogenetic analysis of $\mathrm{CP}$ nt sequences revealed that the Alaska RPV isolates formed three distinct clades: 16 were associated with RPS-Mex 1, six resembled a New York RPV, and 14 formed a unique clade (Fig. 2). The four RPV isolates that were doubly infected with PAS were clustered with NY RPV-like CP (RPV11P1bo3) or with the unique (RPV05P4b02, RPV10P1b03, RPV12P1b03) clade, RPV/RPS recombinant CP (Fig. 2). Within-clade sequence identities of the AK RPVs ranged from 98.5 to $99.5 \%$, which is similar to the Alaska PAS and PAV sequence identities (Table 1). However, unlike PAV and PAS, there was no difference in the level of amino acid identities between RPV CP and ORF4.
While phylogenetic analysis of the RPV CP sequences revealed three distinct clusters, there were only two sequence types based on polymerase gene and intergenic (Pol-IG) region corresponding to nts 2972-3744 of NY-RPV (accession no. L25299). One group shared 98-99\% sequence identity with RPV (isolate names underlined in Fig. 2), and the other group shared $97-98 \%$ sequence identity with RPS (=RPV Mex1). The unique Alaska RPV cluster identified by CP sequence analysis contains isolates with both RPV and RPS Pol-IGs. Discordance between the phylogenies of Pol-IG versus CP suggests recombination has occurred between the two genomic regions. Analysis by PhylPro confirmed the presence of phlylogenetic conflict in two regions (not shown). Sliding window analysis identified likely recombination breakpoints in the sequences alignment between nts 750 and 850, corresponding to nts 3720-3820 (Fig. 3a). In addition, this analysis revealed a second region of phylogenetic discordance in the alignment between nts 1200 and 1260 (nts 4170-4230 of NY-RPV), near the $3^{\prime}$-end of the $\mathrm{CP}$ gene (Fig. 3a). Pairwise sequence analysis revealed that recombination likely occurred between RPV and RPS near the end of the CP gene and that progeny of this recombinant underwent further recombination with RPS (Fig. 3b, c).

The RPV isolates on the Palmer site had more genetic variation within fields and between fields than the PAS isolates (Table 2a, b.) Nst and Snn for the RPV populations were 0.0773 and 0.4000 , respectively. Values were substantially higher between Palmer and Fairbanks sites $(\mathrm{Nst}=0.5581$; $\mathrm{Snn}=0.8838$ ), indicating genetic differentiation of RPV between the two locations. Genetic diversity of the longer RPV sequences (which, in addition to the $\mathrm{CP}$ gene, contained the intergenic region and $3^{\prime}$-end of the polymerase gene) within sampled sites ranged from 0.0166 to 0.0790 . Estimates of genetic differentiation of RPV isolates from Palmer sites $(\mathrm{Nst}=0.1047 ; \mathrm{Snn}=0.6134)$ were similar to those using only coat protein sequence data. As with PAS and PAV, none of the total variation observed among Alaska RPV isolates was due to between-host difference using AMOVA. Ten percent of the total RPV variation was due to differences among the three years of this study. 

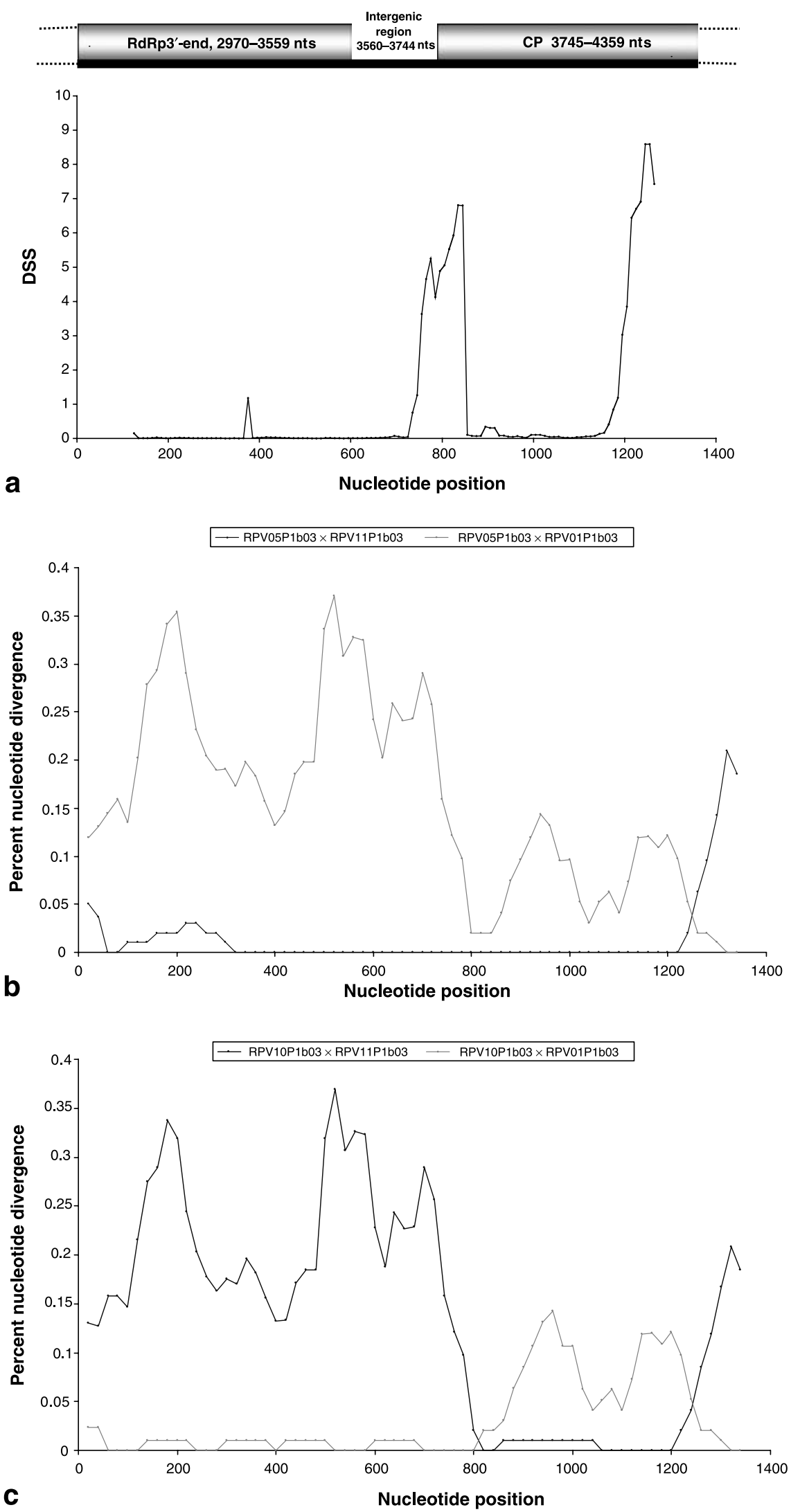

Fig. 3. a Plot of difference of sums of squares (DSS) of phylogenetic discordance [16] versus nucleotide position calculated from an alignment of 24 Alaskan Cereal yellow dwarf virus (CYDV)-RPV isolates plus RPV NY and RPS. Peaks in DSS values indicate likely recombination breakpoints, with $95 \%$ confidence level $>4$. Nucleotide coordinates 750-850 correspond to nts $3720-3820$ of the RPV-NY (L25299) genome and encompass the $3^{\prime}$-end of the intergenic region and the $5^{\prime}$ - first 75 nts of the CP gene. Nucleotide coordinates 1200-1260 correspond to nts 4170-4230 of NY-RPV, near the 3 -end of the $\mathrm{CP}$ gene. b Plot of pairwise nucleotide sequence divergence (sliding window size $=100$; step size $=10$ ) between recombinant isolate RPV05P1b03 and 'parental' isolates RPV11P1b03 and RPV01P1b03. These are not the actual parental sequences, as actual recombination events took place in the past. The recombination junction is approximately at nt 1245 . c Plot of pairwise nucleotide sequence divergence (sliding window size $=100$; step size $=10$ ) between recombinant isolate RPV10P1b03 and 'parental' isolates RPV11P1b03 and RPV01P1b03. Recombination junctions are at nts 800 and 1245 


\section{Discussion}

One of the most striking results from this population study is the exclusive occurrence of isolates most similar to PAS and not PAV in South Central Alaska. The PAS serotype was first detected in New York in 1994 as a PAV variant, PAV-129 [3], and later classified as a distinct species, BYDV-PAS, in the genus Luteovirus [5, 15]. BYDV-PAS is noticeably different from many other PAV isolates in that it causes more stunting/discolouration on oat plants, breaks BYDV resistance in "Ogal" oats, and although it reacts to PAV polyclonal antibodies, it is not reactive to PAV monoclonal antibody $1 \mathrm{C} 2$ [3]. Based on the unique RFLP profile associated with PAV-129 isolates from field surveys in New York, Chay et al. [3] speculated that the PAV-129 isolate was probably widespread in New York and most likely occurred in other distant geographical regions. In fact, Mastari et al. [14] confirmed the presence of PAV-129-like isolates in France and Morocco between 1994 and 1997. Based on surveys confined to a small region in France and RFLP/SSCP from PCR fragments of the CP gene, over half of their 110 isolates were similar to PAV129, (i.e. PAV FL2, Fig. 1), whereas the remaining PAV isolates were more similarly grouped together with the other known PAV isolates (i.e. PAV FHv1, Fig. 1). Another study analyzed the CP sequences of 12 Morocco PAV isolates and divided them into two clusters, aligning seven isolates (i.e. PAV MA9508, Fig. 1) with PAV-129, and five isolates with PAVs from Japan, USA, and Australia [1]. Only PAV-like isolates were found in Illinois [19].

In northern Europe, where climatic conditions are similar to the long photoperiods and relatively cooler temperatures of Alaska's growing season, Bisnieks et al. [2] reported six PAV isolates from Sweden (PAV Sweden, PAV Storvreta) and Latvia (PAV Saldus 1, -2, PAV Priekuli 1, -2) that were similar to each other (except a distinct variant, PAV Saldus 1). The five Alaska PAV isolates from Fairbanks formed a separate cluster that associated with these Swedish/Latvia isolates, and not the PAS isolates from Palmer (Fig. 1). Thus, PAS-like isolates are now known to occur in Alaska, New York, France, and Morocco. Most likely, BYDV-
PAS will be found in other geographical regions as well. The lack of PAV-like isolates in South Central Alaska is not understood, especially since PAS-like isolates have always been detected with PAV isolates (same site but different plants) in France, New York, and Morocco [1, 3, 14]. Although the PAS-like isolates did not have a host preference relative to barley and oats in Alaska, Masteri et al. [14] detected a definite PAS preference for barley over ryegrass in France, and Chay et al. [3] only found the PAS in maize and winter wheat in New York. Native perennial grasses in Alaska are possibly better overwintering hosts for PAS, providing a virus reservoir for aphid transmission to barley and oat crops during the growing season. Preferential PAS transmission by aphid vectors in South Central Alaska may also account for PAS as the dominant viral species.

Cereal yellow dwarf virus-RPV is similar to PAV in its ubiquitous presence in agricultural regions that cultivate grass and cereal species. Overall, fewer AK (Alaska) RPVs (36) were detected relative to PAS/PAVs (151), and only four plants proved to be infected by both. Phylogenetic analysis revealed three clear clades of RPV CP sequences, one of which is distinct and consists of recombinants of RPV/RPS CP sequences. Complete genomic sequences are available for NY-RPV [29] and RPS-Mex 1 [17], and there are partial sequences of RPV from Iran [21] and Australia [30]. RPS-Mex 1 is now designated RPS instead of RPV, because ORFs $0-2$ have only $41-81 \%$ sequence identity with their NY-RPV counterparts [17]. Interestingly, over fifty percent of the AK RPVs were related to RPS, and some appear to be similar to the NY-RPV, while others are recombinants between RPV and RPS. Even though the distribution of RPS is currently limited to North America (Mexico, California, and Alaska), it is probable that they co-exist in other regions with known populations of C/BYDVs. More sequence data from RPV isolates from other geographical regions in the world are needed to fully access the uniqueness of the 14 AK RPS-RPV recombinant isolates (Fig. 2). Nevertheless, the recombinant isolates probably represent a stable component of the CYDV population structure in South Central Alaska since they 
occurred every year between 2002 and 2004 in oats or barley on all the sites except P5. From the CP gene sequence data it is apparent that the population compositions of PAS and RPV were essentially constant over the three-year sampling period. This suggests that the overwintering sources for BYDV and CYDV are stable over time. While only one site was sampled in Fairbanks, a tentative conclusion is that Palmer and Fairbanks have different BYD source populations. This is not surprising, since the two geographical locations have different climatic/ environmental parameters and are separated by approximately $500 \mathrm{~km}$ and mountain ranges. Knowledge of differences in alternative and overwintering plant hosts and aphid vectors in Alaska would help us understand the epidemiology of BYD disease in Alaska. Indeed, special attention to C/BYDV surveys of grass species near cereal crops and rangeland grasses and in contrasting regions that are unaffected by agriculture may provide valuable information on the overall population structure for B/CYDV.

This study also provides the first report of likely RPS isolates in Alaska, and the probable recombination in the $\mathrm{CP}$ gene and between the $\mathrm{CP}$ and polymerase-intergenic regions among AK RPV and RPS isolates. We present a temporal study on the genetic structure for plant viruses causing BYD disease from the genera Luteovirus and Polerovirus and show that the population structures of both BYDV-PAS and CYDV-RPV exhibit year-to-year genetic stability, similar to most other plant virus populations $[6,7]$.

\section{Acknowledgements}

We thank K. Brown and C. Hessinger for excellent technical assistance.

\section{References}

1. Bencharki B, Mutterer J, Yamani ME, Ziegler-Graff V, Zaoui D, Jonard G (1999) Severity of infection of Moroccan barley yellow dwarf virus PAV isolates correlates with variability in their coat protein sequences. Ann Appl Biol 134: 89-99

2. Bisnieks M, Kvarnhedon A, Sigvald R, Valkonen JPT (2004) Molecular diversity of the coat protein-encoding region of Barley yellow dwarf virus-PAV and Barley yellow dwarf virus-MAV from Latvia and Sweden. Arch Virol 149: 843-853

3. Chay CA, Smith DM, Vaughan R, Gray SM (1996) Diversity among isolates within PAV serotype of barley yellow dwarf virus. Phytopathology 86: 370-377

4. D'Arcy CJ, Burnett PA (1995) Barley yellow dwarf: 40 years of progress. Edited by C. J. D'Arcy and P. A. Burnett. APS Press, St. Paul, Minnesota

5. D'Arcy CJ, Domier LL (2005) Family Luteoviridae. In: Fauquet CM, Mayo MA, Maniloff J, Desselberger U, Ball LA (eds) Virus taxonomy: Eighth report of the International Committee on the Taxonomy of Viruses, Elsevier Academic Press, San Diego, pp 891-900

6. Gárcía-Arenal F, Fraile A, Malpica JM (2001) Variability and genomic structure of plant virus populations. Annu Rev Phytopathol 39: 157-186

7. Gárcía-Arenal F, Fraile A, Malpica JM (2003) Variation and evolution of plant virus populations. Int Microbiol 6: $225-232$

8. Gárcía-Arenal F, McDonald BA (2003) An analysis of the durability of resistance to plant viruses. Phytopathology 93: 941-952

9. Geske SM, French R, Robertson NL, Carroll TW (1996) Purification and coat protein gene sequence of a Montana RMV-like isolate of barley yellow dwarf virus. Arch Virol 141: 541-556

10. Hudson RR (2000) A new statistic for detecting genetic differentiation. Genetics 155: 2011-2014

11. Lister RM, Ranieri R (1995) Distribution and economic importance of barley yellow dwarf virus. In: D’Arcy CJ, Burnett PA (eds) Barley yellow dwarf; 40 years of progress. American Phytopathological Society Press, pp 29-53

12. Lynch M, Crease TJ (1990) The analysis of population survey data on DNA sequence variation. Mol Biol Evol 7: 377-394

13. Martin RR, D’Arcy JD (1995) Taxonomy of barley yellow dwarf viruses. In: D'Arcy CJ, Burnett PA (eds) Barley yellow dwarf; 40 years of progress. American Phytopathological Society Press, pp 203-214

14. Mastari J, Lapierre H, Dessens JT (1998) Asymmetrical distribution of barley yellow dwarf virus PAV variants between host plant species. Phytopathology 88 : 818-821

15. Mayo MA (2002) ICTV at the Paris ICV: results of the Plenary Session and the binomial Ballot. Arch Virol 147: 2254-2260

16. McGuire G, Wright F (2000) TOPAL 2.0: improved detection of mosaic sequences within multiple alignments. Bioinformatics 16: 130-134

17. Miller WA, Liu S, Beckett R (2002) Barley yellow dwarf virus: Luteoviridae or Tombusviridae? Mol Plant Pathol 3: 177-183

18. Milne I, Wright F, Rowe G, Marshal DF, Husmeier D, McGuire G (2004) TOPALi: software for Auto- 
matic Identification of Recombinant Sequences within DNA multiple alignments. Bioinformatics 20: 1806-1807

19. Moon JS, Allen RG, Domier LL, Hewings AD (2000) Molecular and biological characterization of a trackable Illinois isolate of Barley yellow dwarf virus-PAV. Plant Dis 84: 483-486

20. Oswald JW, Houston BR (1951) A new virus disease of cereals, transmissible by aphids. Plant Dis Reptr 35: 471-475

21. Rastgou M, Khatabi B, Kvarnheden A, Izadpanah K (2005) Relationships of Barley yellow dwarf virus-PAV and Cereal yellow dwarf virus-RPV from Iran with viruses of the family Luteoviridae. Euro J Plant Pathol 113: $321-326$

22. Robertson NL (2003) Luteovirus and polerovirus found in small grains for the first time in the MatanuskaSusitna region of Alaska. Plant Dis 87: 446

23. Robertson NL, French R, Gray SM (1991) Use of group specific primers and the polymerase chain reaction for the detection and identification of luteoviruses. J Gen Virol 72: 1473-1477

24. Rozas J, Sánchez-DelBarrio JC, Messeguer X, Rozas R (2003) DnaSP, DNA polymorphism analyses by the coalescent and other methods. Bioinformatics 19: 2496-2497
25. Schneider S, Roessli D, Excoffier L (1999) Arlequin, version 2.0: a software for genetic data analysis: Genetics and Biometry Laboratory, University of Geneva

26. Sprague R (1955) Check list of diseases of grasses and cereals in Alaska. Plant Dis Reptr Suppl 232

27. Swofford DL (2000) Paup*. Phylogenetic Analysis Using Parsimony (*and other Methods), Version 4.0b8a. Sinauer, Sunderland, MA

28. Thompson JD, Gibson TJ, Plewniak F, Jeanmougin F, Higgins DG (1997) The Clustal_X windows interface: flexible strategies for multiple sequence alignment aided by quality analysis tools. Nucleic Acids Res 25: 4876-4882

29. Vincent JR, Lister RM, Larkins BA (1991) Nucleotide sequence analysis and genomic organization of the NYRPV isolate of barley yellow dwarf virus. J Gen Virol 72: 2347-2355

30. Wang M-B, Cheng Z, Keese MW, Graham MW, Larkins PJ, Waterhouse PM (1998) Comparison of the coat protein, movement protein and RNA polymerase gene sequences of Australian, Chinese, and American isolates of barley yellow dwarf virus transmitted by Rhopalosiphum padi. Arch Virol 143: 1005-1013

31. Weiller GF (1998) Phylogenetic profiles: a graphical method for detecting genetic recombinations in homologous sequences. Mol Biol Evol 15: 326-335 